\title{
Doctor Francis Skaryna and the Heavens: Astrology in the Life of a Sixteenth-Century Book-Printer
}

\author{
BY \\ ULADZIMIR KANANOVICH
}

The focus of this article is the role of astrology in personal life and professional activities by Doctor Francis Skaryna. Although astrology was an essential part of medieval and Renaissance life, this topic has been neglected by biographical scholars of the Belarusian first-printer. Apart from an article on astronomical knowledge of Skaryna by Heorhi Halienčanka (Golenchenko 1979, 54-59), and a recent investigation on the symbology of Skaryna's engravings by Uladzimir Ahijevič (1999), nothing else has been published. This article serves to fill the gap. This article does not focus on the entire complex of astrological knowledge possessed by Francis Skaryna; it investigates the sources of his astrological information.

In order to appreciate the role of astrology in activities by Doctor Francis Skaryna, it is necessary begin with the academic disputes surrounding his birth date. Discussions of Francis Skaryna's date of birth have involved and still involve the interpretation of available astronomical and astrological material. Certain scholars (cited below) maintain that astronomical phenomena that took place on Skaryna's birth date and their resulting astrological interpretations influenced Francis Skaryna's activities later in life.

The exact date of the birth of Francis Skaryna is not clear: earlier scholars from Vladimirov in the late nineteenth century thought he had been born around 1490 (Vladimirov 1888, 44; Nemirovskii 1990, 154). Later scholars, however, reconsidered this date. The famous Belarusian researcher, Mikola Ščakacichin, for example, put forward the hypothesis that Francis Skaryna might have been born in 1486, when a solar eclipse occurred which was visible in his native town of Polack (Ščakacichin 1925, 148-151). According to Ščakacichin, this important event in Skaryna's personal life is reflected in his graphic symbols illustrating the sun and the crescent moon with a human face. This idea was later accepted by a number of scholars, including Evgenii Nemirovskii (1990, 154-156). While there were a few solar eclipses which could have been quite visible in Polack in the 
late fifteenth century, there is scant evidence to connect this astronomical event to Francis Skaryna's date of birth (Halienčanka 2011). Belarusian scholar Uladzimir Ahijevič recently put forward his own argument for Skaryn's birth date. Analyzing the astronomical (and astrological) evidence in a Francis Skaryna self-portrait, Ahijevič came to the very bald conclusion that the Belarusian printer must have been born on the saint George's day (23 April) in 1476 (Ahijevič 1999, 210-232). Quite recently, Uladzimir Paŭlovič, using the forensic iconographical analysis of Francis Skaryna self-portrait, suggested that the Belarusian first-printer might have been born on 12 August 1476 (Paŭlovič 2017, 5). In spite of this, however, most contemporary scholarship accepts 1490 to be Skaryna's date of birth (Halienčanka 2011). In any case, the problem of Francis Skaryna's date of birth still requires a new, a more sophisticated and forensic research approach.

\section{Late Medieval Merchants and Astrology}

This section is concerned primarily with the professional activities of Francis Skaryna's family. It is important to know these activities, because it creates the context for Francis's later education - an education that taught him astrology. In addition, this section establishes a connection between business and astrology. It shows that business in the Late Middle Ages was a risky affair and astrology was seen as a way to counter the many hazards of the marketplace.

Francis Skaryna was born to the family of Luce Skaryna, a merchant of Polack. In the second half of the fifteenth century, burghers, alongside nobility and clergy, constituted a rather privileged community in the town on the Dzvina river. Many of them, including Francis's father, Luce, were largely involved in international trade, especially with Riga and Moscow (Makaraŭ, 2008, 65-67). The most influential merchants of Polack took part in diplomatic negotiations and missions to Riga (Polotskie gramoty, 2, 1978, 51-54, 54-56, 56-57). ${ }^{1}$ In the Livonian capital, the burghers of Polack even possessed their own church, the Saint Nicholas church (Polotskie gramoty, 2, 1978, 57-58). The growing socio-economic and political importance of the burghers of Polack eventually resulted in granting them the Law of Magdeburg in 1498 (Polotskie gramoty, 2, 1978, 153-157). ${ }^{2}$

1 For example, in 1476, the community of Polack, including the burghers of Polack, the bishop Semen II the Younger and the palatine Olechna Sudymontavič, wrote to Riga, in the matter of a certain Hans Smolbach. It emerges from the correspondence that the burghers of Polack, in 1474, employed him for the reconstruction of the Saint Sophia cathedral's bells and even sent him some amounts of copper, money and bread. The subsequent death of Smolbach, between 1474 and 1476, however, seriously hindered the process of reconstruction.

2 According to the law of Magdeburg of 1498, the town was relieved from the authority of a governor and its citizens exempt from custom duties throughout the Grand Duchy of Lithuania. It was now the town's council consisting of twelve members, six of Orthodox and the other six of Catholic faith, and headed by the mayor (vojt) that assumed the full authority in the town's matters. The citizens of Polack were also allowed to build a public bath and to erect a town hall, as well as to hold a fair three 
In the second half of the fifteenth century, mostly due to its strategic position at the middle Western Dzvina (also spelt Dvina or Daugava) and its location at the intersection of the trade routes leading from the west to the east and from the south to the north, Polack had a stable reputation as an important trade hub in Eastern Europe, competing with even the Great Novgorod further in the north. To a great degree, Polack functioned as a kind of trade center through which goods flowed from European markets in the West, mainly via Riga, to oriental markets in the East, including Muscovy and Tartar states. At the time Polack, alongside Kaunas and Smaliensk, was one of the largest and richest towns in the Grand Duchy of Lithuania, following only the duchy's capital, Vilnius (Pietkiewicz 1995, 177).

Scarce evidence of later date, in particular the documents from the archives of Poznan (Isajevič and Čamiarycki 1988, 107-160), reveals that the Skaryna family was likely to had been involved in international trade of skins, and perhaps that of furs and pelts. The court acts of Poznan from the late 1520s give a rather impressive picture of this family's business activities, at least in this commercial center. It appears that Francis's elder brother, John, was very active in Poznan (Posen) and in Prussia, where he led a significant business. A Vilnius citizen and John's relative, a certain Juchno Stefanovič, might have acted as the family's representative in Poznan. Different persons, including Francis Skaryna himself and his wife, Margarethe, as well as Jewish merchants from Warsaw, might have invested heavily into John's venture. Of a probable scale of the business that John Skaryna might have conducted in Poznan itself at the time tells us clearly the amount of skins which were kept in the basement under the house of Jacob Corb, who was a citizen of Poznan and an assumed business partner of John Skaryna. According to the above-mentioned court records of Poznan, there were in total 47,468 skins of different size and quality, including the lynx pelts, found in Corb's house (Isajevič and Čamiarycki 1988, 112-123).

Conducting business was extremely risky and failures were a constituent part of contemporary reality. Indeed, in the surviving diplomatic records of 1492, Francis Skaryna's father, Luce, alongside a certain Prokofiev (possibly also from Polack) are accused by the Muscovite authorities to have robbed a merchant from Great Luki, a small town north-east of Polack, named Doronia Ivanov (Isajevič and Čamiarycki 1988, 45-46; Nemirovskii 1990, 42). This fact shows how risky and even dangerous commercial activities in the late Middle Ages might have been. The activities of Francis Skaryna himself clearly reveals the risky side of contemporary business activities. His Rus'ian Bible project was never completed, perhaps, because of financial difficulties. Further, a series of court processes, in which Francis Skaryna was consequently involved in the late 1520s and early

times a year. As for the city's responsibilities, its inhabitants were obliged to pay to the grand ducal treasury 400 kops of hroshy each year. 
$1530 \mathrm{~s}$, seems to have destroyed his entire business and might have served as a catalyst in his decision to leave Lithuania.

In these uncertain circumstances, when economic science was still in a nascent state, men of business often turned to astrology (Burckhardt 1995). It was commonly believed that the heavenly signs would foretell a success or a failure of a future business endeavour. Such an appeal to the stars, indeed, was not been something strange or unusual at the time. Astrology was an integral part of late medieval and early modern culture; astrologers appear to have been highly respected and influential persons (Burckhardt 1995, 335-336). Not only powerful princes, but also rich entrepreneurs often consulted the stars to predict the outcome of their ventures. Jacob Fugger, a famous banker and financier in Central Europe, is known to have retained a personal fortune-teller to consult him before going to embark on his new deal (Jardine, 1996, 111). In the age of incalculability of a business risk, people of business actively sought any possibility to predict the results of future business operations (Eamon 2011b). The stars were asked whenever an entrepreneur wanted to fix a favourable time for an action (Burckhardt 1995, 336-337).

\section{Liberal Arts and Astrology}

It is very likely that some of the wealth Luce Skaryna accumulated as a merchant he invested into education of his children. This section argues the education of Francis Skayrna was a possible tactical element of Luce's wider business strategy. It will also be shown that knowledge of astronomy and astrology were essential parts of a higher education where Skaryna studied in Cracow.

There is a strong possibility that Luce appreciated the value of knowledge and education. He lived in a time when the written word was making great progress in the Grand Duchy of Lithuania. There is no doubt that Francis grew up in literate family. It is known from later documents that the members of Luce's family were well versed in written Rus'ian (Ruthenian). John Skaryna's debt note, for example, was recorded in this language (in vulgari Ruthenico) (Isajevič and Čamiarycki 1988, 113).

Before entering Cracow, Francis Skaryna himself, except his native Rus'ian (Ruthenian, old Belarusian), an indispensable tool of diplomacy and business activities in Eastern Europe in the late Middle Ages, must have been well versed in Old Church Slavonic, a liturgical language in the Grand Duchy of Lithuania and in the whole region. He also possessed the knowledge of Latin, that was indispensable for his studies at Cracow, mainly due to the presence of the Franciscans (and Bernardines) in his native town. Thus, the arrival of the written word in this part of globe in the late Middle Ages might have impacted literacy among businessmen 
in the Grand Duchy of Lithuania, ultimately producing a potential readership for a new commodity, the printed book.

Education is very likely to have been part of the Skaryna family's strategy aimed at acquiring a high social status and personal prestige. Study at a University allowed Francis Skaryna to establish himself as a person of virtue and nobility. It is therefore not surprising that Francis Skaryna's business partners often spoke of him as the very honorable Francis Skaryna, a doctor from Vilna, "egregious vir Franciscus Skorynin, doctor de Vilna" (Isajevič and Čamiarycki 1988, p. 95). But education might have had a more practical application for the Skaryna family. By the early sixteenth century, European merchants and bankers already saw education and expertise as a basis for further commercial expansion and personal prosperity (Jardine 1996, p. 223). To some extent, the Skaryna family might have been pioneers in the Grand Duchy of Lithuania in this regard. They seem to have been one of the first merchant families in Lithuania who decided to send their members to a university.

In the early sixteenth-century, the basic University course covered the seven liberal arts, including grammar, rhetoric, logic, music, arithmetic, geometry, and astronomy. Astronomy (and its extension astrology), alongside music, arithmetic and geometry, was part of "quadrivium", which, together with "trivium" (grammar, rhetoric and logic), was structural for a student in liberal arts (Nemirovskii 1990, 177-186).

It is safe to say that Francis Skaryna must have acquired his initial knowledge in astronomy during his student years at Cracow. Any student involved in liberal arts and medicine had to have requisite knowledge in astronomy. Astrology was generally linked to astronomy, being its practical branch (Kanas 2009, 79). As such, this discipline had blossomed since the early thirteenth century, when it appeared at the court of emperor Frederick II Hohenstaufen in Italy (Burckhardt 1995, 334-335).

During the late Middle Ages, Cracow firmly established itself in the world of astronomy. In this city, in the first half of the fifteenth century, the most prominent expert in astrology was a certain Master Henry, a man of Czech descent and professor at the Jagiellonian University. According to the fifteenth century Polish annalist John Dlugosz, it was namely Henry whose advice was usually asked by the Queen Safija Halšanskaja for each of her three births. Consequently, he drew horoscopes for each of her three children. That the fifteenth-century rulers repeatedly turned to astrology is not strange: not only the Jagiellonians but also other European ruling families, like, for example, the ducal Sforza family in Milan, did in a similar way (Azzolini 2005, 183-205).

In the second half of the fifteenth and early sixteenth centuries the schools of mathematics and astronomy blossomed at Cracow. The city was the only center of 
learning, at least in Eastern Europe, that maintained separate chairs of astronomy and astrology. The fame of Cracow as one of the leading schools of astronomy in late medieval Europe was largely epitomized by the name of the greatest sixteenthcentury astronomer, Nicholas Copernicus, who studied liberal arts here in 14911494 (Rowell, 2002, 24-25). In this sense, Cracow was close to Bologna, which had its own Professor of Astrology who taught a four-year course in this discipline (Kanas 2009, 79).

Famous scholars who taught astronomy in Cracow during Francis Skaryna's education included John of Glogów and Martin Bem (Nemirovskii 1990, 184-186). Such well-known late medieval and Renaissance astronomical and astrological texts as John of Sacrobosco's (John of Hollywood in England) Sphera (in interpretation of John of Glogów) may have made their way to a young student from Polack. The practical study of astronomy-astrology at a University necessarily included not only the reckoning of paschaliae but also the composition of different kinds of calendars and horoscopes. In doing so, students tried to explain the influence the stars and other heavenly bodies might have exerted on both human organs and human endeavors (Kanas 2009, 79-80).

Doctor Francis Skaryna is likely to have been a good student in astronomy (Golenchenko 1979, 54-59). Skaryna mentions this science among the seven liberal arts in his preface to his published Bible. For Skaryna, such Biblical texts as the Genesis, the Book of Joshua of Nun, the Books of Kings, and the Gospels served as an important source of astronomical knowledge (Koršunaŭ and Čamiarycki, 1990, 46-47).

Not everywhere in late medieval Europe was the relation to astrology so friendly. If the use of astrology was usual in Western and Central Europe, including Poland and Lithuania, this science was still considered as diabolic trumpery in the neighboring Muscovite state. Thus, some of the regions where the Skaryna family conducted business frowned upon astrology. A famous Muscovite intellectual of the first half of the sixteenth century, Maximus the Greek, a famous contemporary Orthodox monk and religious author, for example, in his letter to a Muscovite bojar named Fedor Karpov, severely condemned the latter's interest in astrology, thus following the disapproval it had gained from certain Fathers of the church, including in particular Saint Augistine (Grek 1996, 206-225). Maximus the Greek also appealed to an unknown prince with the same condemnation of astrology (Grek 1996, 263-270). In general, the critics of astrology hold an important place in the whole literary legacy of this prolific author, who possessed a large knowledge and experience of occident scientific tradition during his intellectual sojourn in Italy in the 1490s and early 1500s, where he was especially influenced by Savanarola's sermons (Kanas 2009, 82). All the same, whatever his motives 
and despite the possibility of offending trading partners from the east, Luce Skaryna funded the education of his bight son, Francis, who learnt the twin arts of astronomy and astrology.

\section{Skaryna and Astrology: Iconographic Evidence}

An attentive look at a Skaryna self-portrait betrays the author's expertise in astrology. It serves as evidence of both his learning in astrology and the importance he attached to it. The Skaryna self-portrait in question initially appears in the biblical book of Jesus of Sirach (5 December 1517); we see this again in the fourth book of Kings (10 August 1518). The portrait also re-appears in the book of Genesis (1519) (Nemirovskii 1990, 380-385).

To begin with, the portrait clearly depicts Skaryna sitting at his desk in his study with a pen in his right hand; he is also surrounded by books (Barazna 1972, 33-35). The theme of the scribe at the work table surrounded by books was quite a common representation in late medieval and Renaissance prints. Bearing in mind Skaryna's education and profession, one suggests that his portrait may have been inspired by a similar picture in a well-known medieval botanical treatise, De vivibus herbarum (On the properties of plants) (Flood 1976, 62-65; Macer Floridus 1506).

To continue, in the left corner of the Skaryna self-portrait is the armillary sphere that is very similar to Peter Apian's sphaera mundi (Cosmographia 1564, f. B iii). Peter Apian (Apianus) was a well-known sixteenth-century German mathematician, instrument-maker and scientific publisher (Kanas 2009, 89-90). His principal work was Cosmographia largely based on Ptolemy and first published in 1524. Apian's sphere served for reckoning of the position of heavenly bodies. In the Skaryna selfportrait, it is clearly seen that an ecliptic is inclined to the equator; to the north and to the south of the equator are shown the tropics of Cancer and Capricorn (Ahijevič 1999, 164). Also, an armillary sphere in the Skaryna self-portrait reveals a striking similarity with a sphere in George Peuerbach's work, Tabulae Eclypsium, which appeared in Vienna just three years before Skaryna embarked on the printing of the Rus'ian Bible in Prague (Peuerbach 1514).

There is also a certain similarity with Regimontanus' globe as depicted in his well-known treatise On Triangles. A woodcut in this work shows Regiomontanus conversing with Ptolemy, with an armillary sphere depicted above the sitters (Regiomontanus 1496, f. 3b). Regiomontanus, whose initial name was Johann Müller, was a talented mathematician and astronomer, who lived in the second half of the fifteenth century (Kanas 2009, 86). ${ }^{3}$ His greatest works, such as On Triangles and Table of Eclipses (in collaboration with his Nuremberg mentor Georg of Peuerbach),

\footnotetext{
For more about Regiomontanus, see Zinner (1968).
} 
largely influenced Nicholas Copernicus' principal work On the Revolution of the Celestial Spheres (Jardine 1996, 350-352). Regiomontanus also built a workshop in his native Nuremberg in 1471, where he made astronomical instruments, such as quadrants, astrolabes and armillary spheres. Like any of the astronomers and mathematicians of his day, he was involved in astrology, making nativities and predictions for his patrons. Regiomontanus was one of the first one who started scientific publishing in Europe. It is worth noting that his major prints included Ephemerides for the years 1475 through 1506 (Kanas 2009, 87). Regiomontanus's Ephemerides were largely used by Christopher Columbus and Amerigo Vespucci in their explorations of America. This work was highly popularized by various printers, including Radtold in Venice (Gingerich 1975, 91, note A).

Another symbol in the Skaryna self-portrait, that is, the image of a sun and a crescent moon may also have been influenced by Regiomontanus. As such, it dates back to the famous Regiomontanus's calendar. This astronomical calendar was first edited in Nuremberg in 1474, where Regiomontanus set up his printing press around 1471, after his short-term stay in Hungarian Buda. Regiomontanus' calendar was more than just a calendar; it was a compendium of mathematical and astronomical information, for practical and educational purposes. It also included phases of the Moon, calculations of Easter, and tables of predicted solar and lunar eclipses up to 1530 . What was particularly innovative in his work are diagrammatic depictions of total and partial solar and lunar eclipses (Simcock 2017).

Regiomontanus calendar enjoyed an enormous popularity with a learned audience: it was reprinted, often with additions and revisions and in different languages (Latin, German, Italian), in the early sixteenth century. These prints contained numerous high-quality woodcuts (Zinner 1968, 125-128). An edition prepared by Hans am Wasen in Zurich in 1508, Ein Kalender mitt sinem Nüwen und Stunden us des hochgelerten Doctor Iohannis Kungspergers Practic unnd sunst vil subtiler Sachen mit vil Figuren als man am nechsten Blatt lütrer Meldung findt, still holds a particular place in the history of this calendar; it was printed as twice as large in comparison to previous editions, augmented with useful information on the influence of planets and signs, practical astrological medicine, etc. What is especially interesting is that the edition of 1508 was the first one that contained the spectacular image of the crescent moon and the sun (Kalendar 1508, f. 54). If we compare this image in Regiomontanus's calendar with the well-known images from the Rus'ian Bible, we find their striking similarity (See figure 1).

There is no doubt that Francis Skaryna was aware of Regiomontanus' astronomical works in general and his calendars in particular. Regiontanus' works were largely known in late medieval Cracow and their presence in this city is well attested in local libraries (Dobrzycki 1988, 69-90). In fact, Regiomontanus's 
calendar, alongside his Ephemerides, enjoyed an increased popularity in this part of Europe. Regiomontanus' astronomical works were quite accessible on other locations in late medieval Central and Eastern Europe. Stephen Rowell recently suggested that the Regiomontanus' calendar may have been a principal source for Skaryna's paschaliae for 1523-1543 so meticulously calculated in the Little Traveller's Book (Liber Viaticus) (Rowell 2002, 30-31).

Alongside the image of the sun and moon, two other devices on shields in the Skaryna self-portrait are worth consideration. They are traditionally treated either as coats of arms of Francis Skaryna's family, both from paternal and maternal sides, or tradesmen's (printer's) marks (Pichura 1967, 155). In the context of our current discussion, however, it is very possible that these devices may have possessed an astronomical (and astrological) meaning. The first sign, which has a form of a triangle, may have meant a celestial constellation called Trianglus, triangle, one of the principal constellations in the sky. What may the second device, a figure similar to rectangular with a cross above it, have meant is more difficult to say. But if we continue our logic, it is plausible to suggest a celestial constellation. Further, Uladzimir Ahijevič recently suggested that the image of a bee (fly) in the Skaryna self-portrait might have meant a constellation called Musca (Ahijevič 1999, 210-232). However, a list of the constellations listed in Apian's Astronomicum Caesareum, as well as other contemporary astronomical treatises, does not mention a constellation with this name (Apian 1540, f. 3). This very fact makes the author's argumentation especially weak.

Nevertheless, Ahijevič is absolutely right to suggest the decorations of many capital letters in Skaryna's prints of Prague may mean particular celestial constellations, including the Gemini, Hercules, Pisces, Cancer, Serpent, Capricornus, etc. (Ahijevič 1999, 217).

Thus, the presence of the armillary sphere, the appearance of solar and lunar symbols, and other assumed astronomical images in the Skaryna self-portrait certainly betrays a scholar experienced in astronomy-astrology. In particular, plants visible in the Skaryna portrait suggest his proficiency not only in botany but also in astrological medicine, since the latter was closely associated with the administration of herbal treatment. There is no doubt that as a physician by profession, Francis Skaryna might have been well versed in astrological medicine, which, as a particular branch of medicine, sought to establish links between human health and the position of stars in the heaven. Indeed, astrological medicine, which dated back to classical times, was especially popular in Renaissance Europe. This branch of medicine was indeed an important part of curriculum at the time (Šutava 2015, 20-22). ${ }^{4}$ Such medico-astrological texts,

4 See a substantial discussion of the medical curricula at Italian Universities in general and at Padua 
as Diebus criticis by Galen and Guillelmus Anglicus's De urina non visa, were essential to study (Azzolini 2005, 190-193). ${ }^{5}$ In particular, the theory of critical days was considered as one of the pillars of astrological medicine (Azzolini 2005, 188-189, 196). Renaissance physicians often used astrological medicine to treat their patients, both in terms of a prognostication of an illness and of a medication. According to the main tenets of astrological medicine, medications had to be administered at a certain time to ensure the best remedy and the favourable influence of celestial bodies (Azzolini 2006, 197). It was practiced at courts of many rulers in Renaissance Europe, especially in Italy (Azzolini 2006, 185-189). ${ }^{6}$ The Skaryna self-portrait itself certainly betrays the author's medical activities and his expertise in astrological medicine $\mathrm{s}$ as well. ${ }^{7}$

\section{Francis Skaryna in Prague: the Rus'ian Bible and a Spectacular Astronomical Event}

In the early sixteenth century, the opportunity to produce printed texts was clearly identified by the entrepreneurs as a lucrative business opportunity, and the organization of the printing trade was clearly seen as part of extremely sophisticated commercial world (Jardine 1996, 150).

Skaryna is most likely to have been the kind of businessman who was alert to current trends in business and was prepared to invest heavily to them, even at the cost of risk. We cannot exclude that the perspective of producing a book in print was again seen by Francis Skaryna as a business opportunity, suggested by an existing stable demand for a print of a particular kind in the market. In Skaryna's case, this kind of a print was a Bible.

Such attitudes towards business was surely shared by many of Francis Skaryna's colleagues, both merchants and intellectuals, who often acted as press-owners, bookdistributors, and editors. Contemporary humanists, whose narrow circle Doctor Francis Skaryna definitely belonged to, often worked as international promoters of the print trade. The activities of Erasmus of Rotterdam can indisputably serve as

in Šutava's work. The scholar says, however, nothing about astrological medicine in the curricula at Italian Universities.

5 Azzolini discusses at length the curriculum for medical students at Bologna. The author strongly suggests that the curricula at other Italian universities may not have differed considerably from that of Bologna. There is also an extensive scholarship concerning astrology in the curriculum of Italian universities in her article.

6 See more about the theory and practice of astrological medicine in Renaissance Europe in Azzolini's work.

7 Consult, for example, the Casebooks Project as a digital edition of the medical records of two London physicians, Simon Forman and Richard Napier, in 1598-1634, initiated by the University of Cambridge. Available at: http://www.magicandmedicine.hps.cam.ac.uk/. The professional activities of Forman and Napier clearly reveals their keen interest in astrology and close involvement in astrological prognostication. That might have been the case of Doctor Francis Skaryna. 
the best example: throughout his long career this scholar widely cooperated with the most famous and renowned printing houses in Europe (Jardine 1996, 200-201).

Doctor Francis Skaryna began working on his print project on 6 August 1506. The first book on which he embarked was the Psalter. A detailed preface to this book contains also an exact date of its first successful printing: leta po bozh'em narozheniiu tyseshchnogo piatsotogo i semogonadeset' meseca avgusta, dnia shestago (Koršunaŭ and Čamiarycki 1990, 10). On this date, according to the Julian calendar, fell one of the greatest Christian feasts, namely the Transfiguration of Jesus Christ. There is no concern that the Belarusian printer, as a religious man, might have consciously chosen this date, which symbolized the highest point in Christ's earthly life.

The first sign of the connection of astrology to the print project is the apparent completion date of the first printing. The date of 6 August 1517, seems to have been very particular: it was strongly defined by an extraordinary astronomical event. It appears that on this day, when the sun was travelling across the zodiacal sign of Leo, the brightest and most spectacular star of this constellation, called Cor Leonis (Pectus Leonis, Basilica) in Latin and Calb Eleced in Chaldean, raised and later set in the August sky. Indeed, Cor Leonis appears in the sky exclusively during a single day; that day was exactly the sixth August (see Petrus Apian 1540, f.4). Francis Skaryna as an experienced scholar in astronomy might have been well aware of this star, which appears in the sky on a concrete date. He is most likely to have believed that the appearance of this star in the August sky foretold him a future success of his endeavour.

The sign of Leo itself was believed to have had a great, mostly positive influence on both human spirit and body. With the sun in Leo, it was considered the ideal time to begin new endeavours, like building houses and constructing towns (Kalender 1508, f. 29). There is also a clear relation between the sign of Leo and the Sun: Leo is astrologically defined as the House of Sun. In the Regiomontanus' calendar, for example, Leo is allegorically defined as the Sun's kiss, Der loew ist der sunnen kuss (Kalender 1508, f. 57). Moreover, according to ancient biblical history, a lion is considered as a symbol of the House of Juda, a leading fraction of the chosen people. As such, the sign of Lion corresponds to the prophet Helias, whose name in Hebrew simply means a sun (Morozov 2004, 320, 322, 343).

Astrologically, the date 6 August 1517 is of particular interest as well (See figure 2). According to the famous contemporary almanac of Johann Stöfller, on this day, in 1517, the combination of celestial bodies was believed to guarantee the success of any deal (Almanach, f. 12). The almanach was very popular in Skaryna's day (Gingerich 1975). The almanac gave necessary knowledge in different areas of astrology, including also an astrological medicine; it contains, for example, 
information of when and how administer herbs, or to make bloodletting, and so on, practices that were also linked to astrology.

The almanach could have also informed Skaryna about the position of the moon on 6 August 1517, was to influence his work. The moon in a trine with the sun in Leo suggests the protection of rulers and other great men (Almanach 1499, f. 12). The trine aspect of the moon and Saturn was seen as beneficial for different kinds of human practical activities; this conjunction would have a positive effect on agricultural activities (planting trees, in particular) and founding new settlements (also fortifying strongholds) as well (Almanach 1499, f. 13). In turn, Jupiter in trine with the moon, in turn, meant the absence of a hinder for any deal: oiacque opera sine ullo timore incipiat (Almanach 1499, f. 12). Finally, Venus in trine with the Moon was considered to favourable for any kind of amorous relations (Almanach $1499,13)$.

Below some dates are listed, on which Doctor Francis Skaryna embarked on printing different Biblical books, in terms of astrology. Astrological information concerning those days is offered with subsequent analysis of it. The almanac of Stöffler serves as a main source of information.

Book of Job: the tenth September 1517. The Moon is in sextile aspect with the Sun (Almanach 1499, f. 298).

Book of Proverbs: the sixth October 1517. The Moon is in sextile with the Sun and in trine with Venus (Almanach 1499, 299).

Book of Joshua of Sirach: the fifth December 1517. The Moon is in conjunction with Jupiter and in square with Mercury (Almanach 1499, 301).

Book of Ecclesiastes: the second January 1518. The Moon is in trine with the Sun and in square with both Mars and Mercury, Mars being in conjunction with Mercury (Almanach 1499, f. 304).

Canticum Canticorum (Song of Songs): the ninth January 1518. The Moon is in conjunction with Saturn, Mars and Mercury, and Venus being in sextile with Mercury (Almanach 1499, 304).

Book of Wisdom: the nineteenth January 1518. The Moon is in trine with Jupiter and Mercury, and in sextile with Venus; Mars and Venus being in opposition (Almanach 1499, f. 304).

Book of Joshua of Nun: the twentieth December 1518. The Moon is in sextile with Jupiter and Mars, and in trine with Venus and Mercury (Almanach 1499, 315).

Book of Judith: the ninth February 1519. There is no information in Stöffler's Almanach (Almanach 1499, f. 319). 
Book of the Judges: the fifteenth December 1519. The Moon is in square with Saturn and Venus, in sextile with Mars, and in trine with Mercury (Almanach 1499, f. 329).

Now we turn to a part of the almanac's part called Electiones in initiis operum. It gives valuable advice, in terms of astrological aspects, when to begin any important endeavor. To begin with, the relations of the Moon with the Sun are dominated by very harmonious aspects, such as a trine, sextile, which means a propitious time for human initiatives (Almanach 1499, f. 12). The trine aspect of the Sun with the Moon means protection for rulers and asks for justice. As for sextile aspect between the Sun and the Moon, this combination makes easier communication and dealing with authorities (Almanach 1499, f. 12). The same positive aspects also determine the combinations of the Moon with the planets, such as Jupiter and Mercury. The relations of trine, sextile and conjunction prevail the relations of Jupiter with the Moon. Jupiter in trine with the Moon is believed to be in extremely beneficial time for any kind of activities, (Almanach 1499, f. 12). Jupiter in sextile with the Moon is commonly considered as a good time for doing any things, bona opera incipere (Almanach 1499, f. 12). Jupiter in conjunction with the Moon is believed to be favorable for communication with judges, nobility and ecclesiastical authorities (Almanach 1499, f. 13). The relations of Mercury with the Moon are mostly dominated by the aspects of square and conjunction. Mercury in square with the Moon means a beneficial time for making calculations and reckoning, diplomatic activities, trade and commerce, as well as for operations with iron and other metals, etc. (Almanach 1499, f. 13). Mercury in conjunction with the Moon is commonly considered as a beneficial time for any kind of written work, making calculations, trade and travelling (Almanach 1499, f. 13).

All the above-mentioned days are very astrologically favourable dates upon which an undertaking is to be taken. Therefore, while the evidence above does not necessitate that all of Francis Skaryna's business undertakings were based upon astrological calculation, there is a strong correlation to suggest that certain important projects, like his Rus'ian Bible, were planned according to astrological signs.

\section{Skaryna in Vilnius: Liber Viaticus and Eschatological Expectations}

The later prints by Francis Skaryna provide a firmer evidence of his use of the Stöfller Almanach. This evidence comes mostly from the Paschaliae, which alongside the Psalter, is believed to have constituted the most significant part of the Little Traveller's Book (Liber Viaticus), which was published by Skaryna in Vilnius in 1522. This book was intended to serve as a practical device for all people who had to spend a lot of time on a road, including especially merchants. As for 
the Skaryna's Paschaliae, this book contained the information concerning the dates of the principal Christian feasts, Easter in first lieu, as well as the celestial constellations and eclipses of the moon and the sun for the years 1523-1543 (Koršunaǔ and Čamiarycki, 174-175, 180).

As for the assumed relation between Skaryna's Paschaliae and Stöffler's Almanach, astronomical information for the year 7032 according to the Byzantine reckoning of time (1524 according to the Julian calendar) contained in the Paschaliae is of special attention for a researcher. Before Skaryna focuses on the most significant movable and unmovable Christian feasts for the year 7032, he particularly mentions that this year is a leap year (visekst in old Belarusian). He especially notes that that there will be no solar and lunar eclipses this year. Instead, as Francis Skaryna goes on, there will be a great conjunction of seven stars - which he does not identify, however - in the zodiacal sign of Pisces, that corresponds to the month of February: such an extraordinary celestial combination would produce unparalleled mutations of kingdoms, laws, people, and all beings living on earth and on waters, if only God Himself allows this, Skaryna concludes (Koršunaŭ and Čamiarycki, 96):

In this year there will be no disappearance of the sun or moon, but there will be a conjunction of all seven wandering stars in the heavenly sign of Pisces in the month of February, which signify, by the leave of God, great changes in the future for the kingdoms, laws, people and all creatures born on earth and in water, the like of which has never happened before (translation: Nadson 1972, 349).

An attentive comparison of the above-mentioned text in Skaryna's Paschaliae with a corresponding place in Stöffler's Almanach betrays essential similarities between the both. It worth noting particularly that in his popular almanac, the German scholar mentions a spectacular conjunction of seven celestial bodies in the sign of Pisces for the year 1524, which would suggest the greatest changes on the earth; he is, however far from predicting the future catastrophe for the humankind in any form. Instead, he called on humankind for penitence concluding his prognostication with the following words: raise, Christian folk, your caps (levite viri christianissimi capita vestra) (Almanach 1499, f. 389).

So, there is no doubt that for Doctor Francis Skaryna, when he was to embark on his Paschaliae, Stöffler's Almanach might have served as a principal source. Regiomontanus calendar could have provided an additional piece of information, of a more general character (Kalender, ff. 143-144). What is especially interesting in this case is that both scholars, Johann Stöffler and Francis Skaryna, believed that the future catastrophe would not be so imminent for the humankind; they connected it with God's goodwill and the repentance of humankind. For them, the 
will of God was much stronger than the constellation of the stars! It was God but not stars that governed human lives.

The above-mentioned information for the year 1524, which was so ushered in by many prophecies of misfortunes and even an earthly catastrophe, might have produced a strong feeling of fear in contemporary European intellectual milieu and common people and eventually resulted in numerous apocalyptic prophecies, such as that by Johan Lichtenberger, one of the most famous Renaissance German stargazers (Crouzet 1999, 5; Eamon 2014c, 180). Lichtenberger, like many of his colleagues, relying most likely on the Stöffler's almanac, predicted the imminent end of the world in a form of a second Deluge. This information was quickly spread by means of sermons, rumours and broadsides (Eamon 2011a).

Eventually it reached a faraway Muscovy, where it found its severest critic in a person of Maximus the Greek (Grek 1996, II, 278). It is interesting enough that Maximus the Greek considers the almanac as the main source of the prophecy of the future imminent Deluge on the earth. He is most likely to have not read the almanac, since he ascribed to the almanac's author what the latter had never written. The eschatological expectations of the year 1524 must surely have produced some kind of trouble in the Grand Duchy of Lithuania, with apocalyptical ideas sneaking mostly from the Holy Roman Empire, where the Protestant Reformation started in 1517. The peculiarity of eschatological movement in the Empire was its close relations with astrology (Crouzet 1999, 3). Hopefully enough for human civilization, this prophecy never materialized, and humankind safely survived the year 1524 (Eamon 2011a).

Astrology in Vilnius in the 1520s seems to have been experiencing a kind of blossoming. This appeal to astrology is most likely to have been caused by particular circumstances involving a royal family. Upon his return to Vilnius in the early 1520s, Skaryna found Polish-Lithuanian courtly society expecting an appearance of a successor. Nothing that depended upon the stars seems to have been more important for King and Grand Duke Sigismund the Elder (1506-1548) than the expectation of his heir. Especially, the very fact that the Queen Bona had not given birth for a long time might certainly have caused various rumours and suspicions. It is understandable that in these circumstances a royal family - and not only they - turned to astrology.

To some extent, one can conclude, the widespread practice of astrology at the courts of Lithuanian grand dukes and dignitaries may be connected with the arrival of future Queen Bona Sforza to Poland and Lithuania in 1518. It is a well-known fact that the Sforza family possessed a rich and a long experience in astrology. Notwithstanding the advices of astrologers, the above-mentioned situation with the grand ducal heir was happily solved: in 1522 Queen Bona gave a birth to a son, a 
future king Sigismund August (1548-1572). But earlier, in 1529, at age of seven years, he was elevated to a grand duke of Lithuania.

This history, however, had later repercussions. In 1525, in his famous memorial to Queen Bona, Albert Gastold, a contemporary grand ducal chancellor and palatine of Vilnius (1522-1539), who was in conflict with the Radziwill family at the time, accused Nicholas II Radziwill, his predecessor in the offices of chancellor and palatine of Vilnius (1509-1522), that the latter had commissioned a pool of astrologers from different countries of Europe to draw a false horoscope for the grand duke and King Sigismund the Elder (1506-1548), only to convince the Lithuanian court public that this ruler would never have a male successor. According to Gastold, the late Nicholas Radziwill, whose family had recently been elevated to a ducal status by the Emperor Maximilian I (1493-1519), in doing so, attempted to make himself the grand duke (Acta Tomiciana, vol. 7, 260). There is no doubt that such accusations were determined mostly by political considerations, that is, by Albert Gastold's intention to compete against his political rivals. Nevertheless, this case reveals a growing role of astrology in the life of the courtly society in the Grand Duchy of Lithuania.

Just nine years after the haunting expectations of 1524 had finally passed, in 1533 , Europe began to experience a new wave of apocalyptical fears. It was again the Ephemerides by Johannes Stöffler, which revealed at least twenty-six conjunctions of the Moon with Mars and Saturn, generally considered as malevolent planets, must greatly have contributed to the atmosphere of trouble and panic throughout Europe (Crouzet 1999, 6). As a consequence, different almanacs foretold the coming of false prophets, natural disasters, like floods and earthquakes. In particular, the appearance of a comet in the sky in 1532 was conceived as a bad omen. Especially, with the arrival of the year 1533, the expectations of Doomsday became more tensed.

Similar eschatological expectations must surely have reached Vilnius. It is very probable that an epidemic that ravished the city in 1530-1533 could easily have been explained in eschatological terms. It was local Franciscans who had been eventually made scapegoats for the epidemics in Vilnius: they were sent outside the city, where they nearly all died (Nemirovskii 1990, 505). According to some contemporary scholars, like Nemirovskii, the persecutions launched by secular authorities of Vilnius against local Franciscans, could have compelled Francis Skaryna, who is credited to have been close to this monastic order, to leave Lithuania.

It is unknown, however, how Skaryna might have reacted to the wide-spreading eschatological anguish in Europe. In all probability, he continued to believe in the will of God, which governs any constellation of the planetes, as did other humanists, like Francois Rabelais, at that time (Crouzet 1999, 7-8). On the other 
hand, however, after such a devastating court process for his business and a shortterm incarceration in Poznan, he might have felt himself especially destroyed, both physically and morally, even if he had been finally exonerated by a royal decree. In his desperate personal situation, having experienced so many hardships and misfortunes during the last years, the apocalyptical expectations of the year 1533 could have played the role of catalyst in Skaryna's decision to leave his native country.

\section{Conclusions}

Astrology, from the time of Francis Skaryna's student years, was part of his education and outlook. Such popular works of the time, like, for example, Regiomontanus' calendar and Stöffler's almanach, must have influenced his interest in astrology. Skaryna's self-portrait, as well as his printed works, the Paschaliae especially, reveals his involvement in both in astronomy and astrology.

Doctor Francis Skaryna himself appears as a scholar and entrepreneur, who might have appealed to astrology when it was necessary to fix the hour for his endeavors. It is very likely that the process of embarking on the printing of the Rus'ian Bible was firmly set on an astrological framework. Planning the printing of the Rus'ian Bible, Skaryna, like many of his contemporary colleagues-businessmen in Europe, would in all probability have consulted the almanacs and calendars, especially those edited by Stöffler and Regiomontanus, in order to choose the appropriate date to embark on his printing project. However, there is no evidence that he did this on a regular basis.

It is very likely, however, to consider Skaryna's turn to astrology in terms of his personal outlook, in which eschatology and apocalypticism must have played an important role. Could, therefore, Skaryna's printing and publishing activities in 1517-1525 be explained through the eschatological tension in contemporary Europe and which was shared by many of his European colleagues? Francis Skaryna's works are eschatological indeed, and therefore his personality cannot be wholly understood if one neglects his eschatological and apocalyptic beliefs, a significant part of which was astrology. If this reasoning is correct, then it appears that the Rus'ian Bible by Doctor Francis Skaryna must have had not only a pedagogical but also a messianic aim, to widespread and publicize God's Words. Future studies, I believe, will elucidate this question. 


\section{References}

Acta Tomiciana, 1857. vol. 7. Ed. Stanislas Gorski. Poznań.

Ahijevič, Uladzimir, 1999. Simvolika graviury Skaryny. Minsk.

Apian, Petrus, 1564. Cosmographia. Antwerpen.

Apian, Petrus, 1540. Astronomicum Caesareum. Ingolstadt.

Azzolini, Monica, 2005. Reading Health in the Stars. Politics and Medical Astrology in Medieval Milan, in Gunther Oestmann; H. Darrel Rutkin; Kocku von Stuckrad eds., Horoscopes and Public Spheres: Essays on the History of Astrology, Walter de Gruyter GmbH, pp. 183-205.

Barazna, Liavon (ed.), 1972. Hraviury Francyska Skaryny. Minsk.

Burckhardt, Jacob, 1995. The Civilization of the Renaissance in Italy. London: Phaidon Press.

Burnett, Charles, 1996. Astrology, in by F. A. C. Mantello and A. G. Rigg eds., Medieval Latin: An Introduction and Bibliographical Guide. Washington: Catholic University of America Press, pp. 369-382.

Crouzet, Denis, 1999. Millennial Eschatologies in Italy, Germany, and France, 1500-1533, Journal of Millennial Studies, vol. I, issue 2, pp. 1-8. Available at: http://www.mille.org/journal.html. Winter 1999. [Accessed 14 December 2017].

The Annals of Jan Dlugosz, 1997. Ed. Maurice Michael. Chichester.

Dobrzycki, Jan. Tablice astrologiczne Jana Regiomontana w Krakowie, Studia Mediewistyczne, vol. 26 (1988), pp. 69-90.

Eamon, William, 2011a. Astrology and Prophecy in Renaissance, [blog] 20 November 2011. Available at: <http://www.williameamon.com>. [Accessed 25 July 2017].

Eamon, William, 2011b. Renaissance Astrology and the Vagaries of Markets, [blog] 27 November 2011. Available at: <http://www.williameamon.com>. [Accessed 25 July 2017].

Eamon, William, 2014. Astrology and Society, in Brandon Dooley ed., A Companion to Astrology in Renaissance. Leiden-Boston: Brill.

Floridus, Macer, 1506. De vivibus herbarum. Paris. Available at: <http:// archive.org/details/hin-well-all-00002301-001>. [Accessed 15 July 2017].

Flood, Bruce, 1976. The Medieval Herbal Tradition of Macer Floridus, Pharmacy in History, vol. 18, no. 2, pp. 62-66. 
Gingerich, Owen, 1975. "Crisis" versus Aestetic in the Copernican Revolution, Vistas in Astronomy, vol. 17 (1975): 85-95.

Golenchenko, Georgii, 1979. Astronomicheskie svedenia v izdaniiakh Frantsiska Skoriny, Knigovedenie, no. 7(14), pp. 54-59.

Grek, Maksim (Prepodobnyj), 1996. Tvorenia, reprint, in 3 volumes, vol. 2: Dogmatiko-polemicheskie sochinenia, Sviato-Troitskaia Lavra.

Halienčanka, Gieorhi, 2011. Francysk Skaryna: u pavucinie versij, stereatypaŭ i mifaŭ. Available at: <http://krytyka.by/by/page/science/kryinitsaznaustva/6758. html>. [Accessed 11 September 2017].

Isajevič, Jaraslaŭ and Čamiarycki, Viačaslaŭ, eds. 1988. Francysk Skaryna. Zbornik dakumientaú i materyjalaŭ. Minsk: Navuka i technika.

Jardine, Lisa, 1997. Wordly Goods. A New History of the Renaissance. London: Papermac.

Kanas, Nick, 2009. Star Maps: History, Artistry, and Cartography. Springer Science and Business Media.

Koršunaŭ, Aliaksandr and Čamiarycki, Viačaslaŭ, eds. 1990. Francysk Skaryna. Tvory: pradmovy, skazanni, pasliasloūji, akafisty, paschalia. Minsk: Navuka i technika.

McMillin, Arnold, 1988. Francis Skaryna’s Biblical Prefaces and Their Place in Early Belarusian Literature, Journal of Belarusian Studies, vol. 6-1, pp. 3-11.

Morozov, Nikolai, 2004. Velikaia Romeia - pervyj svetoch srednevekovoi kultury. Moskva: Kraft.

Nadson, Alexander, 1972. Skaryna's Prayer Book, Journal of Belarusian Studies, vol. II, no. 4, year VIII, pp. 339-356.

Nemirovskii, Yevgenii, 1990. Frantsisk Skaryna. Zhizn'i deiatelnost' belorusskogo prosvetitelia. Minsk: Mastackaja litaratura.

Paŭlovič, Uladzimir, 2017. Simvaličnaje i reaĺnaje na hraviurach Franciška Skaryny. Minsk: Halijafy.

Peuerbach, Georg von, 1514, Tabulae Eclypsium. Vienna.

Pichura, G, 1967. The Engravings of Francis Skaryna in the Biblija Ruska (1517-1519), Journal of Belarusian Studies, vol. 1-3, pp. 147-167.

Pietkiewicz, Krzyztof, 1985. Wielkie Księstwo Litewskie pod rządami Alexandra Jagiellończyka. Studia nad dziejami państwa i spoleczeństwa na przelomie XV I XVI wieku. Poznań: Wydawnictwo Naukowe UAM. 
Polotskie gramoty XIII-nachala XVI veka, 1978. Ed. Anna Khoroshkevich, vol. II. Moscow: Nauka.

Regiomontanus, Johannes, 1496. Epitoma in Almagestum Ptolemaei. Venice.

Regiomontanus, Johannes, 1508. Ein Kalender mitt sinem Nüwen und Stunden us des hochgelerten Doctor Iohannis Kungspergers Practic unnd sunst vil subtiler Sachen mit vil Figuren als man am nechsten Blatt lütrer Meldung findt, Zürich. Available at: <http://www.e-rara.ch/zuz/content/titleinfo/2780005>. [Accessed 23 July 2017].

Rowell, Stephen, 2002. The Jagiellonians and the Stars: Dynasty-Sponsored Astrology in the Fifteenth Century, Lithuanian Historical Studies, vol. 7, pp. 23-42.

Sacrobosco, Johannes de, 1519. Sphera materialis: eyn anfanck oder fundament der ghenen die da lůst haben zů der kunst der Astronomy, Cologne. Available at: <https://phaidra.univie.ac.at/detail_object/o:176977>. [Accessed 11 September 2017].

Simcock, Tony, 2015. Regiomontanus: The Man in the Moon. Inside MHS Oxford. Stories from the Museum of the History of Science, University of Oxford blog, [blog] 5 February 2015. Available at: <www.blogs.mhs.ox.ac.uk/insidemhs/ Regiomontanus-man-moon>. [Accessed 15 July 2017].

Šmataŭ, V, F., 1990. Mastactva bielaruskaj knihi XV- siaredziny XVI st., in J. Isajevič and V. Čamiarycki eds., Skaryna i jaho epocha. Minsk: Navuka i technika.

Stöffler, Johannes and Pflaum, Jakob, 1499. Almanach nova plurimis annis venturis inservientia, 1499-1531. Ulm. Available at: http://daten.digitalesammlungen.de/db/002/bsb 00029607/images/. [Accessed 18 July 2017].

Šutava, Voĺha, 2014. Once again about Skaryna in Padua. New Possibilities of Reading the Old Documents, Belarusian Review, vol. 26, no. 4 (winter 2014), pp. 17-23.

Šutava, Voĺha, 2015. Once again about Skaryna in Padua: Circumstances, Belarusian Review, vol. 27, no. 1 (spring 2015), pp. 23-28.

Tabulae astronomice divi Alfonsi regis Romanorum et Castelle, 1518-1521. Venice.

Zinner, Eduard, 1968. Leben und Wirken des Johannes Müller von Königsberg, genannt Regiomontanus. Osnabrück. 


\section{4}

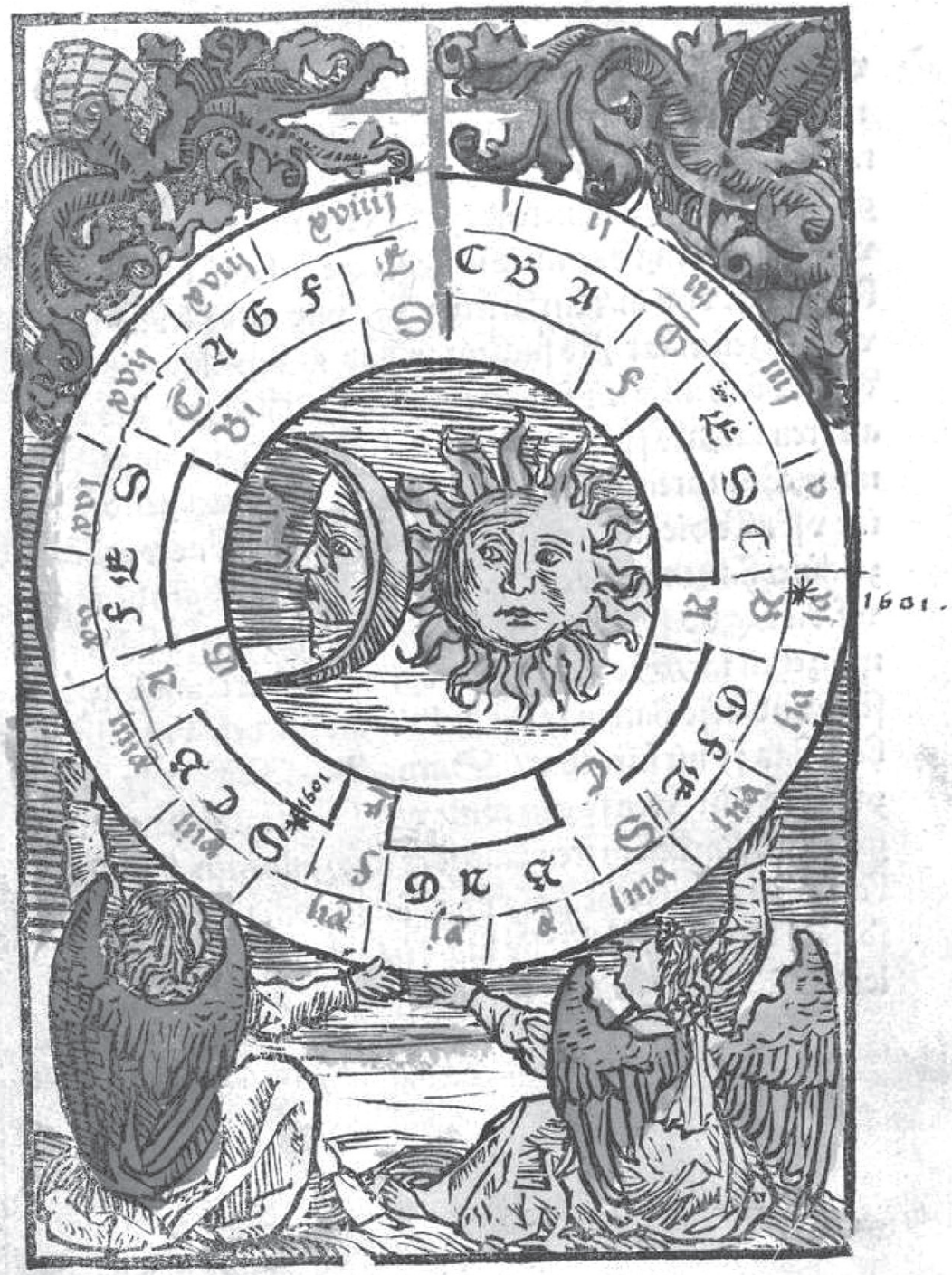

Figure 1. The image of the sun and the crescent moon as depicted in the calendar of Regiomontanus printed in Zurich in 1508. Source: Regiomontanus, Johannes, 1508. Ein Kalender mitt sinem Nüwen und Stunden us des hochgelerten Doctor Iohannis Kungspergers Practic unnd sunst vil subtiler Sachen mit vil Figuren als man am nechsten Blatt Lütrer Meldung findt, Zürich. S. 54. Available at: <http://www.e-rara.ch/zuz/content/ titleinfo/2780005>. [Accessed 23 July 2017]. 


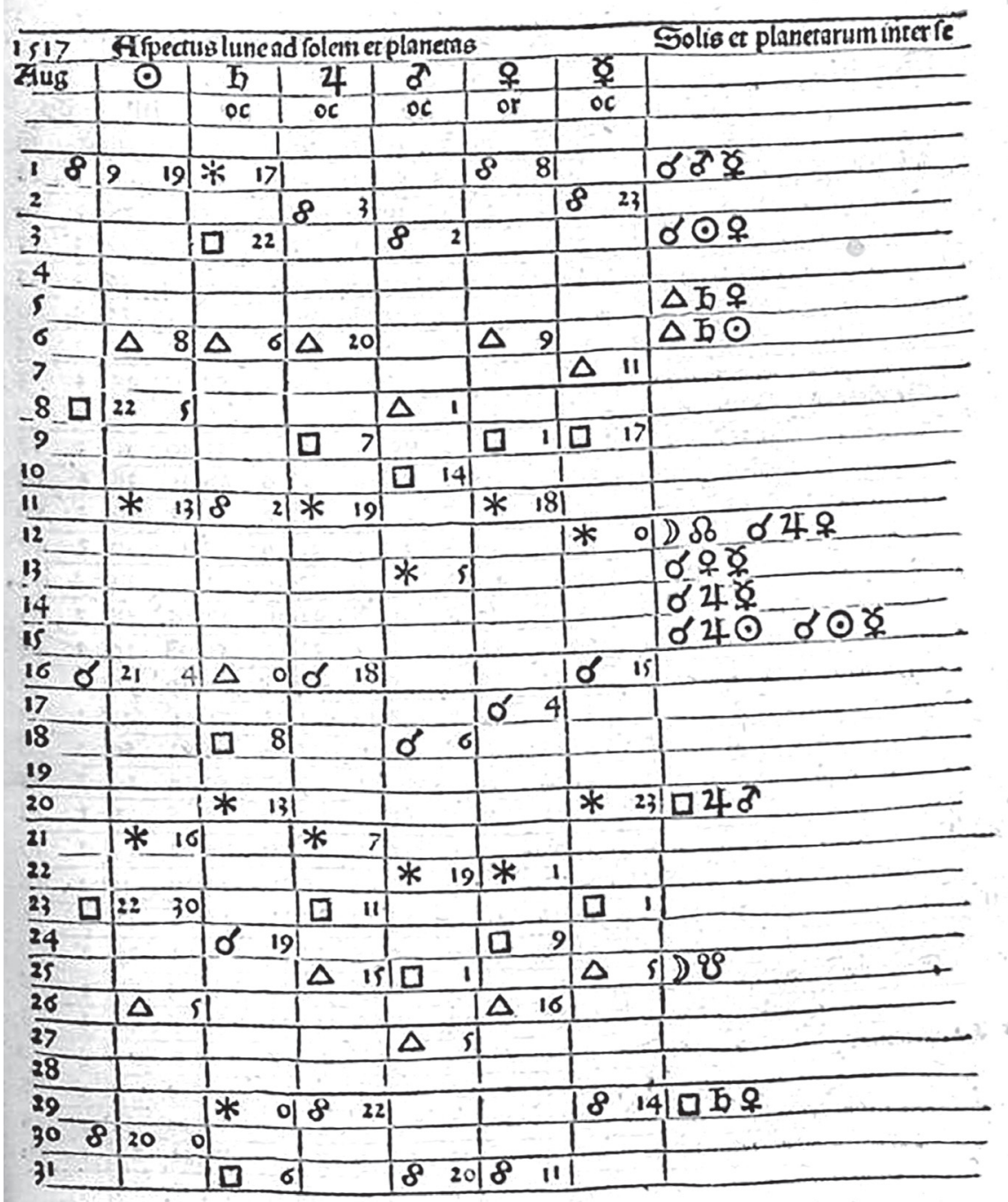

Figure 2. Stoeffler's astronomo-astrological prognostication for the August sixth, 1517, when the first print - the Psalter - was completed. Source: Stöffler, Johannes and Pflaum, Jakob, 1499. Almanach nova plurimis annis venturis inservientia, 1499-1531, Ulm. S. 297. Available at: <http://daten.digitale-sammlungen.de/ db/0002/bsb00029607/images $>$. 